\title{
Identification and Characterisation of a Bacterial Isolate Capable of Growth on Trichloroethylene as the Sole Carbon Source
}

\author{
Piyali Mukherjee, Pranab Roy* \\ Department of Biotechnology, Burdwan University, Burdwan, India \\ Email: piyalimkhrj8@gmail.com, pranabroy@rediffmail.com
}

Received April 23, 2012; revised May 28, 2012; accepted June 13, 2012

\begin{abstract}
The aim of this research work was to isolate microbes from soil, to investigate their potential use as effective bioremediation tools for trichloroethylene - a potent environmental pollutant. The isolate showing good growth in presence of TCE was named PM102. Microbiological characterisation of the PM102 isolate showed that it was a gram negative rod. Detailed structure was revealed by scanning electron microscopy. $\mathrm{pH}$ and temperature optima, salt tolerance and optimum TCE concentration for growth of PM102 were determined. The ability of this bacterium to degrade TCE was studied in acidic and neutral $\mathrm{pH}$ by biochemical test and chloride release. Five TCE inducible bands were detected in the protein profile of the isolate as studied by SDS PAGE. A major TCE inducible band of $51.61 \mathrm{kDa}$ was excised from the gel and injected into rabbit to raise specific antibody. The bacterium was identified as Stenotrophomonas maltophilia PM102 by 16S rDNA amplification and sequencing. The 16S rRNA gene sequence has been deposited in the NCBI GenBank with accession number JQ797560. This genus has not been described previously as being capable of TCE degradation. We report for the first time a Stenotrophomonas sp. that grows on TCE as the sole carbon source.
\end{abstract}

Keywords: Trichloroethylene; Sole Carbon Source; Bioremediation

\section{Introduction}

Trichloroethylene (molecular formula: $\mathrm{C}_{2} \mathrm{HCl}_{3}$ ) - a volatile, colourless, nonflammable liquid, was discovered by Emil Fischer in 1864 while working on the preparation of tetrachlorethane [1]. Germany began the first commercial production of trichloroethylene in 1910 and the US followed in 1925. Through the years, the amount of TCE production in the world has increased dramatically. According to the World Health Organisation (WHO), TCE is also present in the air we breathe. In 2000, concentrations of TCE measured in urban areas worldwide showed background levels between $<17$ and $109 \mathrm{ng} / \mathrm{m}^{3}$ (actual guidelines recommend $5 \mathrm{ng} / \mathrm{m}^{3}$ ) [2]. In rural areas, levels between 0.10 and $0.68 \mu \mathrm{g} / \mathrm{m}^{3}$ have been reported [3] TCE is commonly used for cleaning of metals by vapour degreasing and as a solvent in adhesives, lubricants, pesticides, electronics, printing, paper, pulp and textile industries [4]. Pioneered by Imperial chemical industries in Britain, its development was hailed as an anaesthetic revolution. TCE is the most frequently reported soil and groundwater contaminant on the National priority list of the US Environmental Protection Agency [5]. Despite its

*Corresponding author. low water solubility, TCE leaches into the residual groundwater. It is highly persistent with a half life of days to several weeks and difficult to degrade. Exposure to TCE is associated with a number of adverse health effects: it is primarily a central nervous system depressant and was found to be carcinogenic in experimental animals [6]. On September 28, 2011, EPA released the final health assessment for trichloroethylene (TCE) to the Integrated Risk Information System (IRIS) database, where it has been characterized as carcinogenic to humans and a human noncancer health hazard affecting the kidneys, liver, male reproductive organs and developing foetus. In recent years, much focus has been laid on the use of microorganisms for the elimination of TCE as it is comparatively low-cost and easier than other conventional processes of decontamination.

A variety of aerobic bacteria have been reported to degrade the pollutant trichloroethylene (TCE) cometabolically when they are grown on aliphatic hydrocarbons [7,8], aromatic hydrocarbons [9-14], ammonium salt $[15,16]$, or propane [17]. There are very few reports of bacterial growth on TCE as the sole carbon and energy source. Kitayama (1997) had reported Pseudomonas aeruginosaJI104 as a potential microbe that can use TCE 
as a sole carbon source [18]. A Bacillus sp. was also reported to be able to grow on medium with TCE as the sole carbon source [19]. Stenotrophomonas $s p$. has been found to play important role in biodegradation of keratin [20], geosmin [21], atrazine [22], p-nitrophenol and 4chlorophenol [23] and monocyclic hydrocarbons [24]. Xanthobacter sp. grown on propene has also been found to degrade TCE [25]. The PM102 isolate reported in this study belongs to the class $\gamma$ proteobacteria (Xanthomonadaceae). This is the first instance where trichloroethylene degradation activity has been found in the genus related to Stenotrophomonas, which grows on TCE as the sole carbon source.

\section{Materials and Methods}

\subsection{Collection of Soil Samples}

Soil samples were collected in sterile plastic bags, from the waste disposal site of the industrial belt in Asansol and Dhanbad. Asansol is a major coal mining and industrial city with a number of iron and steel industries. Dhanbad district across the Barakar river in Jharkhand, India, is also a major mining area. All soil samples were stored at $-20^{\circ} \mathrm{C}$.

\subsection{Isolation of Microorganisms from Soil Samples}

The microorganisms were isolated by serial dilution and plating technique. $10 \mathrm{~g}$ soil sample each was suspended in $100 \mathrm{ml}$ sterile distilled water. The soil particles were allowed to settle down and $1 \mathrm{ml}$ of the supernatant was transferred to $9 \mathrm{ml}$ sterile distilled water containing $0.9 \%$ $\mathrm{NaCl}$. Serial dilutions up to $10^{-6}$ were performed. $0.1 \mathrm{ml}$ from all tubes were spread on plates containing minimal medium with TCE $(2 \mu \mathrm{l} / \mathrm{ml})$. The minimal medium was composed of $(\mathrm{g} / \mathrm{l}): \mathrm{KH}_{2} \mathrm{PO}_{4}: 3 ; \mathrm{Na}_{2} \mathrm{HPO}_{4}: 6 ; \mathrm{NaCl}: 0.5$; $\mathrm{NH}_{4} \mathrm{Cl}: 1 ; \mathrm{MgSO}_{4} .7 \mathrm{H}_{2} \mathrm{O}: 0.5 ; \mathrm{CaCl}_{2}$ : 0.05; agar: $2 \%$; $\mathrm{pH}$ 7.4. The plates were incubated at $37^{\circ} \mathrm{C}$ for $48 \mathrm{hrs}$.

\subsection{Screening of Microorganisms on Medium with TCE as the Sole Carbon Source}

Trichloroethylene (GC 99.5\%) was obtained from Merck Ltd. India. 10 colonies were randomly selected from the serial dilution plates and tested for their ability to grow on TCE as the sole carbon source. The colonies were transferred to tubes containing $5 \mathrm{ml}$ of minimal broth with $0.2 \%$ TCE. The minimal medium composition was same as above (agar omitted). All 10 tubes were incubated at $37^{\circ} \mathrm{C}$ for $72 \mathrm{hrs}$. Growth was absent in 4 tubes. Fujiwara test was done to check for TCE degrading activity in the other 6 isolates. Three isolates designated: PM101, PM102 and PM103 showed positive result in Fujiwara reaction. The PM102 isolate showing maximum
TCE degradation activity was chosen for further investigation. The isolate was grown and subcultured in minimal medium slants with $0.2 \%$ TCE.

\subsection{Morphological and Biochemical Characterisation}

The pure colony thus isolated was characterised by various biochemical tests using the Bergey's manual of Determinative Bacteriology, as summarised in Table 1.

The bacterial culture was streaked on respective plates containing tryptone agar, EMB (eosin methylene blue) agar and blood agar. The plates were incubated at $37^{\circ} \mathrm{C}$ for $24 \mathrm{hrs}$. The different colony characters were recorded.

\section{Scanning Electron Microscopy}

The isolate was grown in $10 \mathrm{ml} \mathrm{LB}$ and pelleted by centrifugation. The cell pellet were washed with phosphate buffer and fixed with gluteraldehyde $(4 \% \mathrm{v} / \mathrm{v})$ for $4 \mathrm{hrs}$.

Table 1. Growth in presence of different carbon source was observed. No growth of the PM102 cells was seen in presence of sucrose even after 72 hrs. Even $3 \%$ sucrose did not give any growth. The PM102 cells were able to grow in medium containing $0.5 \%$ and $1 \%$ of glucose, fructose and maltose.

\begin{tabular}{lc}
\hline Shape & Short rods \\
\hline Lactose fermentation & Non fermentative \\
Gram character & - \\
Oxidase & - \\
Indole & - \\
$\mathrm{H}_{2} \mathrm{~S}$ & + \\
Catalase & + \\
Methyl red & - \\
Vogues proskauer & + \\
Amylase & + \\
Gelatin & + \\
Endospore formation & - \\
Growth & Aerobic \\
pH range & $5-8$ \\
Optimum pH & 5.5 \\
Temperature range & $30^{\circ} \mathrm{C}-42^{\circ} \mathrm{C}$ \\
Optimum temperature & $33^{\circ} \mathrm{C}$ \\
NaCl range & $0.01 \mathrm{M}-1 \mathrm{M}$ \\
Optimum salt concentration & $0.1 \mathrm{M}$ \\
Growth in presence of TCE & $0.1 \%-0.4 \%$ \\
Optimum TCE concentration & $0.3 \%$ \\
\hline & \\
\hline &
\end{tabular}


After centrifugation, the cells were dehydrated by gradually lowering the concentration of alcohol: $95 \%, 70 \%$, $50 \%$. Cells were incubated 30 minutes in each of the alcohol concentrations followed by washing. Finally, the cells were diluted with $50 \%$ alcohol. One drop of this cell suspension was placed on a cover slip and studied with Hitachi, S530 SEM at University Science Instrument Centre, Burdwan University (Figures 1(a) and (b)).

\subsection{Physiological Characterisation}

\subsection{1. pH}

PM102 cells were grown in minimal medium with only TCE as the carbon source $(0.2 \%)$ at $33^{\circ} \mathrm{C}$. pH was varied from 3 to 13. Optimum $\mathrm{pH}$ for growth was determined. $\mathrm{pH}$ was rechecked after the experiment.

\subsubsection{Temperature}

PM102 cells were grown in minimal medium with $0.2 \%$ peptone and $0.2 \%$ TCE and incubated at temperatures ranging from $20^{\circ} \mathrm{C}$ to $45^{\circ} \mathrm{C}$. Growth was determined by measuring O.D. at $620 \mathrm{~nm}$ after 24 hours.

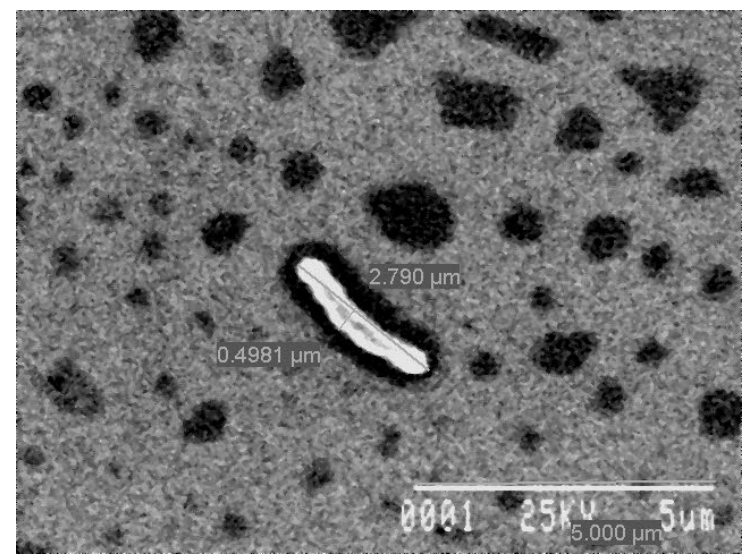

(a)

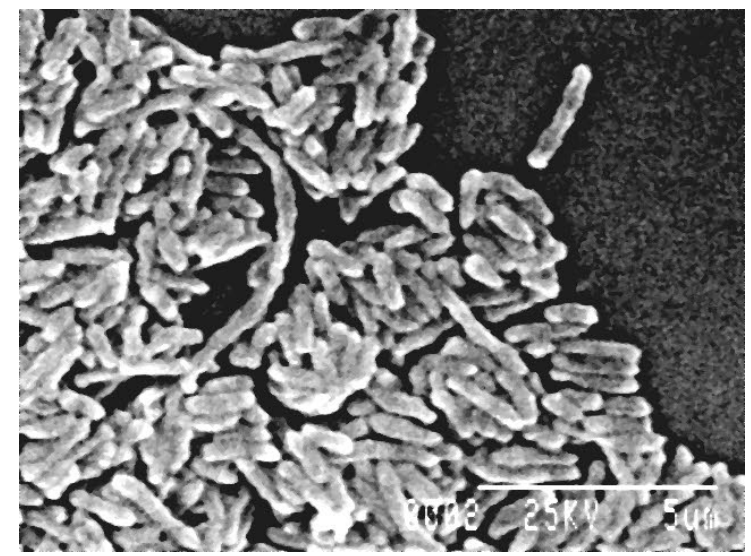

(b)

Figure 1. (a) Scanning electron micrograph of a single bacterium PM102; (b) Scanning electron micrograph of a colony of PM102.

\subsubsection{NaCl Concentration}

Cells were grown in minimal medium at $33^{\circ} \mathrm{C}$, with salt concentration from $0.01 \mathrm{M}$ to $1 \mathrm{M}$. Optimum salt concentration for growth was determined.

\subsubsection{TCE Concentration}

The cells were grown at $\mathrm{pH} 5$ in minimal medium with TCE as the sole carbon source at $33^{\circ} \mathrm{C}$. The amount of TCE added was varied from $0.1 \%$ to $0.5 \%$. We know that excess TCE can inhibit growth as it becomes toxic for the bacteria. Thus, how much TCE can be endured by the PM102 isolate was observed.

\subsubsection{Growth in Presence of Different Carbon Source}

The PM102 cells were grown in minimal medium with $0.2 \%, 0.5 \%$ and $1 \%$ of each of the carbon source respectively: glucose, fructose, maltose and sucrose. The experiment was carried out in sidearm flasks and O.D. was taken at $620 \mathrm{~nm}$ at $24 \mathrm{hrs}, 48 \mathrm{hrs}$ and $72 \mathrm{hrs}$ respectively.

\subsection{Identification of the PM102 Isolate by $16 \mathrm{~S}$ rRNA Gene Amplification and Sequencing}

\subsubsection{DNA Extraction}

Cells obtained from $30 \mathrm{ml}$ culture were resuspended in lysis buffer $[4.5 \mathrm{ml}$ TE buffer, $100 \mu 110 \mathrm{mg} / \mathrm{ml} \mathrm{ly-}$ sozyme, $450 \mu \mathrm{l}$ of $10 \% \mathrm{SDS}, 10 \mu \mathrm{l}$ of $20 \mathrm{mg} / \mathrm{ml}$ proteinase $\mathrm{K}$ ] and incubated for 1 hour at $37^{\circ} \mathrm{C}$. DNA was purified by phenol chloroform extraction and ethanol precipitation (Sambrook et al. 1989).

\subsubsection{S rRNA Gene Sequence and Phylogenetic Analysis}

PCR was carried out by using the universal primers: 27F: 5' AGA GTT TGA TCC TGG CTC AG 3' and 1492R: 5' TAC GGY TAC CTT GTT ACG ACT T 3'. The amplification conditions were: $94^{\circ}$ for $3 \mathrm{~min}$ for the first step, 30 cycles comprising of $94^{\circ}$ for $1 \mathrm{~min}, 52^{\circ}$ for $45 \mathrm{sec}, 72^{\circ}$ for $1 \mathrm{~min}$ and the final extention step of $72^{\circ}$ for $3 \mathrm{~min}$. The PCR product obtained was purified and sequenced by an automated DNA sequencer. The forward and reverse sequences were assembled through DNABaser V35.0 software and submitted to GenBank through NCBI online sequence submission tool: Bankit. MEGA5 software was used to construct phylogenetic tree by aligning PM102 sequence with reference sequences obtained from NCBI GenBank.

\subsection{Determination of TCE Degradation Activity by Fujiwara Test}

Fujiwara test was performed to calculate the amount of trichloroethylene remaining in the medium inoculated with the PM102 isolate. In this reaction, polychlorinated hydrocarbons, in presence of alkali and pyridine gives a 
red coloured compound [26].

PM102 cells were grown in $50 \mathrm{ml}$ King's B medium $\left(\mathrm{Na}_{2} \mathrm{HPO}_{4}-1 \mathrm{~g} / \mathrm{l}, \mathrm{K}_{2} \mathrm{HPO}_{4}-3 \mathrm{~g} / \mathrm{l}, \mathrm{NH}_{4} \mathrm{Cl}-1 \mathrm{~g} / \mathrm{l}\right.$, $\left.\mathrm{MgSO}_{4} \cdot 7 \mathrm{H}_{2} \mathrm{O}-0.4 \mathrm{~g} / \mathrm{l}\right)$ with $0.2 \%$ TCE, at $\mathrm{pH} 5$ and $\mathrm{pH}$ 7 respectively. Cells were pelleted by centrifugation and suspended in $10 \mathrm{ml}$ phosphate buffer with $0.3 \%$ TCE in acetone. As TCE is insoluble in water, it was dissolved in acetone. $\mathrm{pH}$ of the buffer was set at $\mathrm{pH} 5$ and $\mathrm{pH} 7.2 \mathrm{ml}$ aliquot was taken at the beginning (just after inoculation) and after every 30 minutes interval up to 120 minutes and treated with $2 \mathrm{ml} 5 \mathrm{~N} \mathrm{NaOH}$ and $2 \mathrm{ml}$ pyridine followed by heating at $80^{\circ} \mathrm{C}$ for two minutes. Absorbance of the upper red phase was recorded at $470 \mathrm{~nm}$ by spectrophotometer. A control was set up with E. coli. The result of this test was repeated thrice and mean value of absorbance are given. A standard curve was plotted by varying TCE concentration from $0.01 \%$ to $0.48 \%$, from which the amount of TCE remaining at each time point was calculated.

\subsection{Monitoring TCE Degradation by Chloride Release}

As chloride present in minimal medium interferes with this experiment, a chloride free minimal medium$\mathrm{MCl}$, was formulated $\left(\mathrm{K}_{2} \mathrm{HPO}_{4}-3 \mathrm{~g} / \mathrm{l}, \mathrm{Na}_{2} \mathrm{HPO}_{4}-1 \mathrm{~g} / \mathrm{l}\right.$, $\left.\left(\mathrm{NH}_{4}\right)_{2} \mathrm{SO}_{4}-1 \mathrm{~g} / \mathrm{l}, \mathrm{MgSO}_{4} \cdot 7 \mathrm{H}_{2} \mathrm{O}-0.4 \mathrm{~g} / \mathrm{l}\right) .10$ drops of $0.3 \mathrm{M} \mathrm{K}_{2} \mathrm{CrO}_{4}$ was added to the chloride containing medium and titrated against $10 \mathrm{mM} \mathrm{AgNO}$ taken in a burette. Initially, a white precipitate of $\mathrm{AgCl}$ is formed but when free chloride is no longer left in the medium, the solution turns reddish brown due to the formation of $\mathrm{Ag}_{2} \mathrm{CrO}_{4}$. The reaction mechanism is:

$$
\begin{aligned}
& \mathrm{Ag}^{+}+\mathrm{Cl}^{-}=\mathrm{AgCl} \\
& 2 \mathrm{Ag}^{+}+\mathrm{CrO}_{4}^{-}=\mathrm{Ag}_{2} \mathrm{CrO}_{4}
\end{aligned}
$$

PM102 cells were grown in $50 \mathrm{ml}$ of $\mathrm{MCl}$ and at $\mathrm{pH} 5$ and $\mathrm{pH} 7$ and harvested by centrifugation. Amount of TCE added in this experiment was kept within the solubility range of TCE in water i.e. $1.28 \mathrm{~g} / 1(0.128 \%)$. The cells thus obtained were suspended in $10 \mathrm{ml} \mathrm{MCl}$ broth with $0.12 \%$ TCE at $\mathrm{pH} 5$ and $\mathrm{pH} 7$ respectively and titrated against $10 \mathrm{mM} \mathrm{AgNO}$ after every $3 \mathrm{hrs}$ interval, from $0 \mathrm{hrs}$ (just after suspension) to $30 \mathrm{hrs}$. A standard curve was plotted by varying the concentration of $\mathrm{NaCl}$ from $2 \mathrm{mM}$ to $9 \mathrm{mM}$, from which the concentration of free chloride released after the respective time intervals were calculated. The experiment was done in triplicate and mean values of the readings are given.

\subsection{Protein Profile of the Isolate}

The cells were grown in $50 \mathrm{ml}$ minimal medium $\mathrm{pH} 7$, with $0.2 \%$ peptone, $0.2 \% \mathrm{TCE}+0.2 \%$ peptone and $0.2 \%$ TCE respectively at $33^{\circ} \mathrm{C}$ for $48 \mathrm{hrs}$. The cell pellet ob- tained was suspended in $1 \mathrm{ml}$ lysis buffer (10 mM PBS, $1 \%$ SDS, $0.1 \mathrm{mM} \mathrm{PMSF}$ ) for $1 \mathrm{hr}$ at $37^{\circ} \mathrm{C}$. The suspension was centrifuged at $10,000 \mathrm{rpm}$ for 10 minutes at $4^{\circ} \mathrm{C}$ and supernatant was collected. Protein content was measured in each sample by Bradford assay. $40 \mu \mathrm{g}$ of protein was loaded in each well of a $12 \%$ gel and SDS PAGE was carried out. The gel was stained with Coomassie Blue R 250 and destained with $30 \%$ destaining solution. The gel was observed in the gel documentation system (Vilbur Lourmat, France) and analysed with Quantum Capt software.

\subsection{Immunisation of Rabbit to Raise Specific Antibody}

A single TCE inducible band of $51.6 \mathrm{kDa}$ was cut from the gel and homogenised by crushing with a sterile glass rod in Eppendrof tube containing $500 \mu 1$ autoclaved water. A rabbit was injected subcutaneously at 4 to 5 different sites with this protein homogenate mixed 1:1 with Freund's complete adjuvant twice (once per month) followed by two more injections of the same protein homogenate mixed 1:1 with Freund's incomplete adjuvant. To check serum antibody titre, dot blot assay was done. 3 $\mu l$ of the different dilutions $(1: 10,1: 100$ and 1:1000) of antigen i.e., total bacterial protein obtained from TCE + peptone grown cells was spotted onto nylon membrane. 1 $\mathrm{mg} / \mathrm{ml} \mathrm{BSA}$ in different volumes $(1 \mu 1,2 \mu 1,3 \mu \mathrm{l})$ was also spotted on the membrane as control.

\subsection{Western Blot}

The SDS PAGE gel, after electrophoresis (unstained) was electroblotted onto nitrocellulose membrane (Sigma Aldrich USA) at 45 volts for 3 hours. The nitrocellulose membrane was blocked with $3 \%$ milk powder for 1 hour at room temperature and washed thrice with buffer $\mathrm{A}(10$ $\mathrm{mM}$ tris $\mathrm{HCl} \mathrm{pH8,} 1 \mathrm{mM}$ EDTA pH8, 0.05\% tween 20 and $0.9 \% \mathrm{NaCl}$ ), followed by incubation in 1:100 dilution of antiserum in the same buffer, at $4^{\circ} \mathrm{C}$ overnight. Then the membrane was washed with buffer A thrice, five minutes each and incubated in 1:15,000 dilution of Goat antirabbit $\operatorname{IgG}$ coupled to alkaline phosphatase (Sigma Aldrich USA) in buffer A for 2 hours at room temperature. The membrane was again washed in buffer A, 5 minutes each, for three times and equilibriated for 20 minutes in alkaline phosphatase buffer $(100 \mathrm{mM}$ tris $\mathrm{HCl} \mathrm{pH} \mathrm{9.5,} 100 \mathrm{mM} \mathrm{NaCl}$ and $5 \mathrm{mM} \mathrm{MgCl} 2)$. The membrane was stained with BCIP/NBT (5-Bromo,4-Chloro, 3-Indolyl phosphate/Nitrobluetetrazolium) in alkaline phosphatase buffer and kept in the dark.

\subsection{Preadsorption of the Serum Antibody}

$10 \mu 1$ of the peptone grown cellular proteins were spotted on small strips of nitrocellulose membrane and air dried. 
These strips were immersed in 1:100 dilution of the antiserum in buffer $\mathrm{A}$ and incubated by gentle shaking for 1 hour. The strips were removed and the antiserum thus obtained contained antibodies specific only for TCE induced proteins. This process was repeated until all the antibodies against the common antigens were removed.

\section{Results}

\subsection{Morphological, Biochemical and Physiological Characterisation}

Colony formed on tryptone agar was smooth, glistening, opaque with entire margins and pale yellow in colour. Growth on blood agar plates were green in colour with a pungent ammonia odour while growth on eosin methylene blue (EMB) agar plate was of a pale tan colour indicating PM102 to be a lactose nonfermenter. Gram nature of the isolate was confirmed by treating a smear of the culture on a slide with 3\% NaOH. Gram negative PM102 instantly lysed and became viscous whereas a control gram positive bacillus was not affected by the alkali treatment [27].

The results of morphological, biochemical and physiological characterisation of the PM102 isolate are summarised in Table 1.

SEM micrograph reveals that the cells are rod shaped of length $2.8 \mu \mathrm{m}$ and diameter $0.5 \mu \mathrm{m}$. The cells appear to glue to each other forming clusters that may be due to the presence of lipopolysaccharides on the cell surface. (Figures 1(a) and (b)).

\subsection{Identification by $16 \mathrm{~S}$ rRNA Gene Amplification and Sequencing}

The PCR product obtained was checked in $1.2 \%$ agarose gel with 100 b.p. ladder as marker. Bands were obtained at $1.4 \mathrm{~kb}$ (Figure 2). Nucleotide BLAST analysis of the $16 \mathrm{~S}$ rRNA gene sequence of PM102 with 16S rRNA gene sequences retrieved from NCBI GenBank, showed 99\% similarity with Stenotrophomonas maltophilia strain ATCC 19861 which belongs to the class Proteobacteriae and phylum Xanthomonadaceae.

GenBank accession no.: The 16S rRNA gene sequence of PM102 was deposited to NCBI GenBank under the accession no. JQ 797560.

\subsection{Phylogenetic Analysis}

Phylogenetic tree constructed through MEGA5 software using the neighbour joining method revealed that the PM102 clustered homolog were Pseudomonas hibisicola (Acc No. NR024709) and Pseudomonas geniculata NR9024708). PM102 showed the highest level of sequence similarity with Stenotrophomonas maltophilia. (Acc. No. NR040804) (Figure 3).

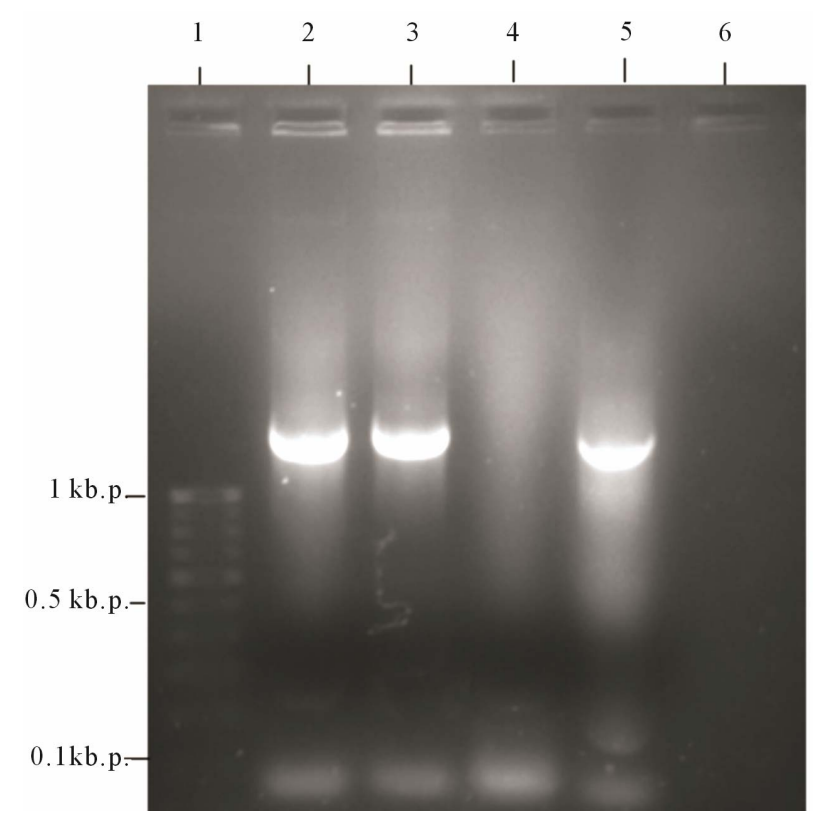

Figure 2. 1.2\% agarose gel of the 16S rDNA PCR product of PM102. Lanes 2, 3 and 5 contain PCR product of $1.4 \mathrm{~Kb}$. Lane 4 had water as control. Lane 1 contains the 100 b.p. ladder.

\subsection{Determination of TCE Degrading Activity by Fujiwara Test}

Out of the three isolates: PM101, PM102 and PM103, the PM102 isolate showed maximum TCE degradation activity (Figure 4(a)). The Fujiwara test for TCE degradation by PM102, showed a decrease in absorbance corresponding to decrease in colour intensity of the upper phase with time, thus confirming TCE degradation. The control setup with $E$. coli gave a parallel graph indicating no change in colour. A standard curve was set up by performing the Fujiwara reaction with varying concentrations of TCE. The percentage of TCE remaining in different set of experiments for PM102 was calculated from the standard curve. The percentage of TCE remaining after 120 minutes at $\mathrm{pH} 7$ was $0.035 \%$ while at $\mathrm{pH} 5$ was $0.069 \%$, of the $0.3 \%$ added initially (Figures $4(\mathbf{b})$ and (c)). From this TCE disappearance assay, it was calculated that $90 \%$ TCE was degraded at $\mathrm{pH} 7$ while $77 \%$ TCE was degraded at $\mathrm{pH} 5$.

\subsection{Monitoring TCE Degradation by Chloride Release}

To further confirm that PM102 was capable of TCE mineralisation, a simple titration experiment was performed to measure the release of chloride ions from TCE by the PM102 isolate. The amount of chloride released by the degradation of $0.12 \%$ TCE by PM102 was found to be $1.5 \mathrm{mM}$ at $\mathrm{pH} 7$ and $1.45 \mathrm{mM}$ at $\mathrm{pH} 5$ after 30 hours respectively. Interestingly, it was noted that chloride 


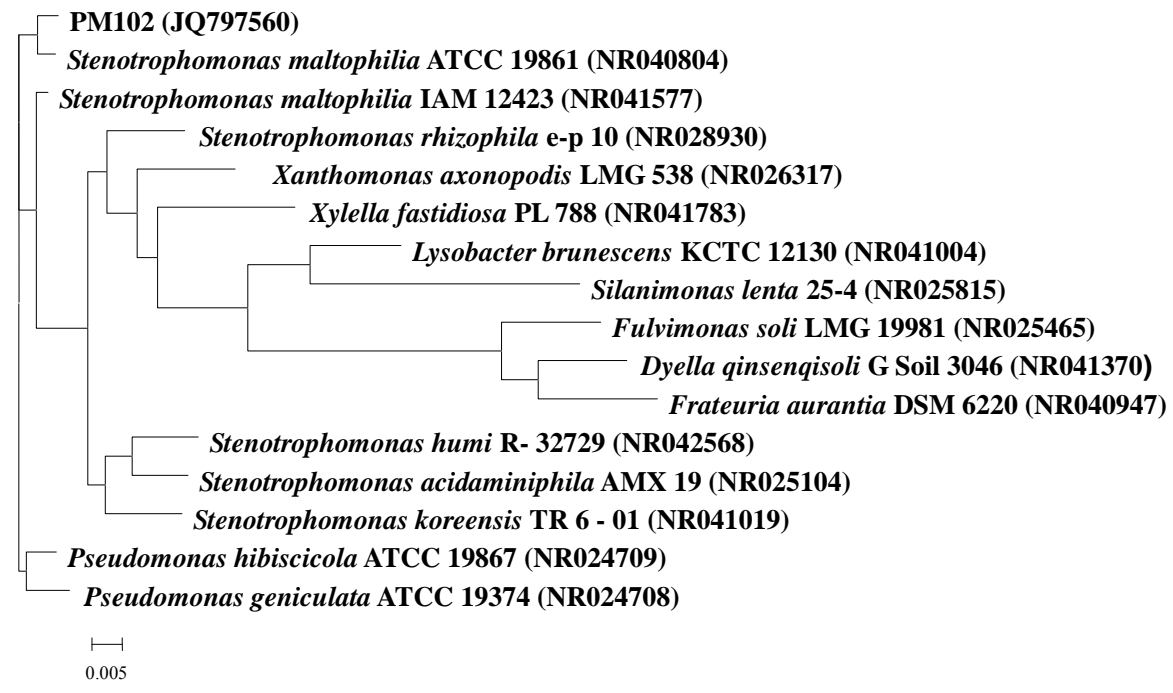

Figure 3. Neighbour joining tree based on PM102 16S rRNA gene sequence comparison with 16S rRNA gene sequences retrieved from the NCBI GenBank, constructed using MEGA 5 software. The numbers in parentheses are GenBank accession numbers.

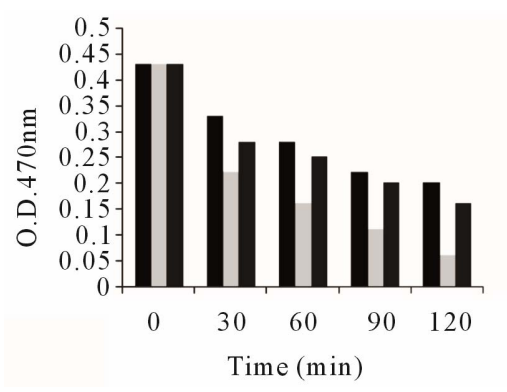

(a)

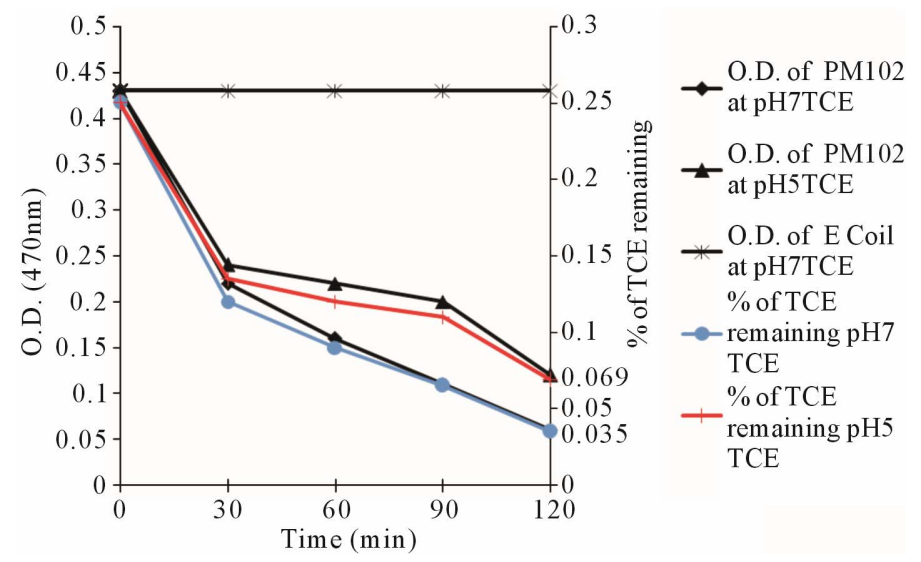

(b)

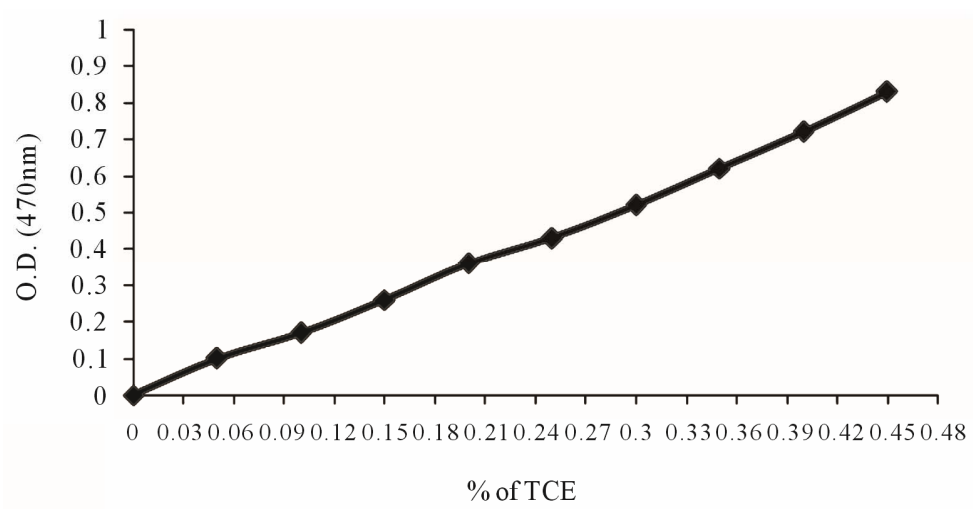

(c)

Figure 4. (a) Comparison of TCE degradation activity of the three isolates: PM101, PM102, PM103 by Fujiwara test; (b) Line graph showing the decrease in absorbance corresponding to the catabolism of TCE by PM102, measured at pH 5 and pH 7 respectively. Secondary vertical axis shows the \% of TCE remaining at different time intervals as calculated from the standard curve. Fujiwara reaction was carried out with $0.3 \%$ TCE, after every 30 minutes interval, till 120 minutes; (c) Standard curve of \% of TCE plotted against absorbance. As \% of TCE added increases, intensity of colour formed after the Fujiwara reaction also increases, causing a rise in $0 . D$. recorded at $470 \mathrm{~nm}$. 
released at $\mathrm{pH} 5$ commenced after a lag period of 9 hours. (Figures 5(a) and (b)). The theoretical amount of chloride released from $0.12 \% \mathrm{TCE}$ is $13.3 \mathrm{mM}$, considering that all the TCE added remains in solution.

\subsection{Protein Profile of the Isolate}

From the total protein profile (Figure 6(a)) obtained by culturing PM102 in the presence and absence of TCE, 5 prominent TCE inducible bands were observed in lane 5, 11 and 12 (TCE). These bands were absent in the absence of TCE as seen in lane 6 and 8 (peptone). These bands are also present in lanes 2, 3, 4, 7, 9 and 10 (TCE + peptone). The molecular weights of these 5 TCE induced proteins are $90.25,51.61,38.83,35.14$ and 20.47 $\mathrm{kDa}$ respectively. The 5 proteins that are produced in response to TCE may be involved in the degradation of TCE. The TCE inducible proteins can be clearly identified in the densitogram (Figure 6(b)).

\subsection{Immunoblotting}

As seen in the dot blot assay, the antiserum reacted with all the dilutions of TCE + peptone grown proteins but no reaction was obtained with BSA (Figure 7). In he western blot analysis with the total antiserum, bands were observed in response to TCE + peptone grown proteins as well as peptone grown proteins (Figure 8(b)). After the antiserum was preadsorbed on peptone grown proteins, response was obtained only for TCE + peptone grown proteins. The preadsorbed antiserum did not react with peptone grown proteins (Figure 8(c)).

\section{Discussion}

Trichloroethylene, one of the major groundwater pollutants throughout the world, is not only an occupational health issue but also a public health concern [Hazardous substance data bank, 2009]. Two important challenges are encountered when one is dealing with bioremediation of TCE. First of all, TCE is almost immiscible in water with a solubility of $1.28 \mathrm{~g} / \mathrm{l}$. Thus, when one is studying TCE degradation, one has to either keep the concentration of TCE within this solubility range or dissolve it in some other organic solvent like ethanol, ether or chloroform - the latter option gets discouraged when one wants to study TCE as the sole carbon source. Studies are underway to demonstrate TCE degradation by an enzymatic assay based on product formation rather than TCE disappearance assay. This would allow the monitoring of TCE degradation rates more accurately. Many microbes have been isolated and characterised that can degrade TCE under laboratory conditions. The second major challenge is to see how effectively these microbes can perform in the given set of environmental conditions. Out of 10 colonies only 3 gave positive reaction in Fujiwara test while maximum degradation was achieved with the PM102 isolate. The PM102 isolate was shown to be able to grow and degrade TCE under neutral as well as acidic $\mathrm{pH}$. This could extend its application to acidic soils as well. There are many reports on cometabolic degradation of TCE and the use of microbial consortia to enhance overall TCE catabolism but research on pure cultures that can grow on TCE as the sole carbon source, as in this

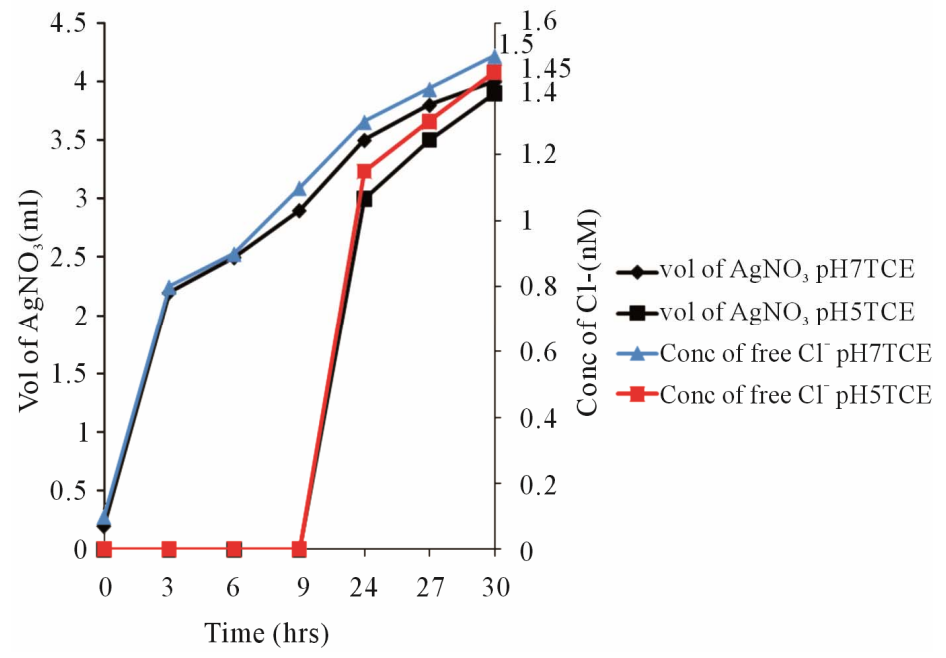

(a)

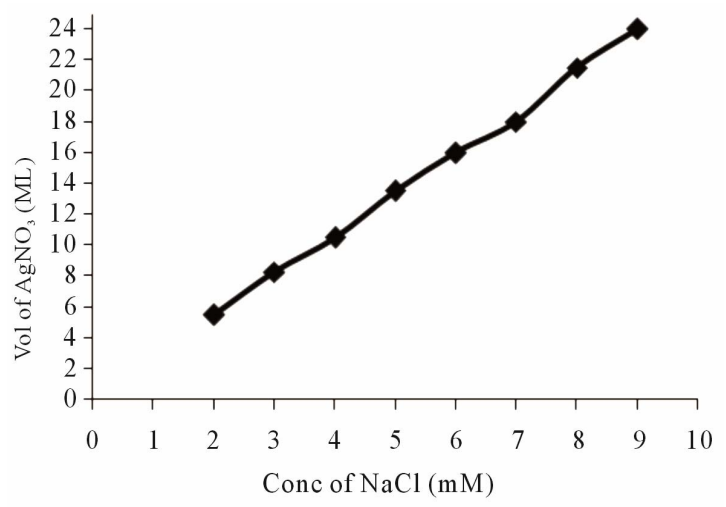

(b)

Figure 5. (a) Plot showing the volume of silver nitrate corresponding to the amount of chloride released. $0.128 \%$ TCE was added initially in a $10 \mathrm{ml}$ reaction volume with PM102 cells. $2 \mathrm{ml}$ of this suspension was taken for titration against silver nitrate, at every 3 hrs interval, up to 30 hrs. The secondary vertical axis shows concentration of chloride released by TCE mineralisation by PM102, at different time intervals, as calculated from the standard curve; (b) Standard curve of chloride estimation plotted by varying concentration of $\mathrm{NaCl}$. 


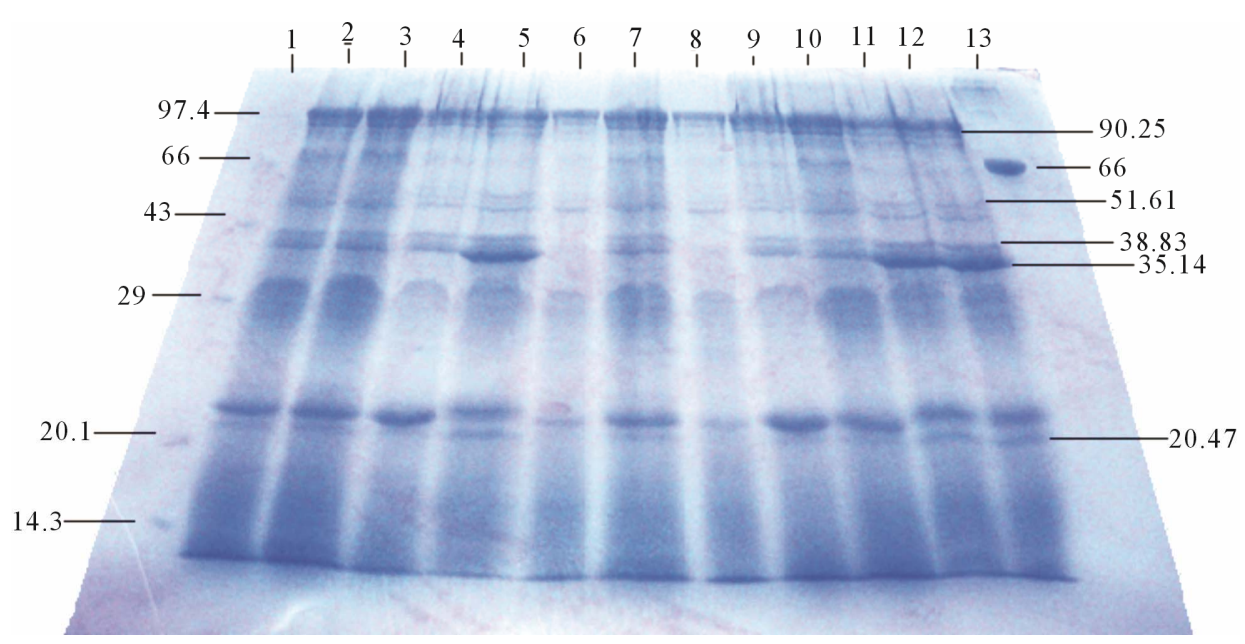

(a)
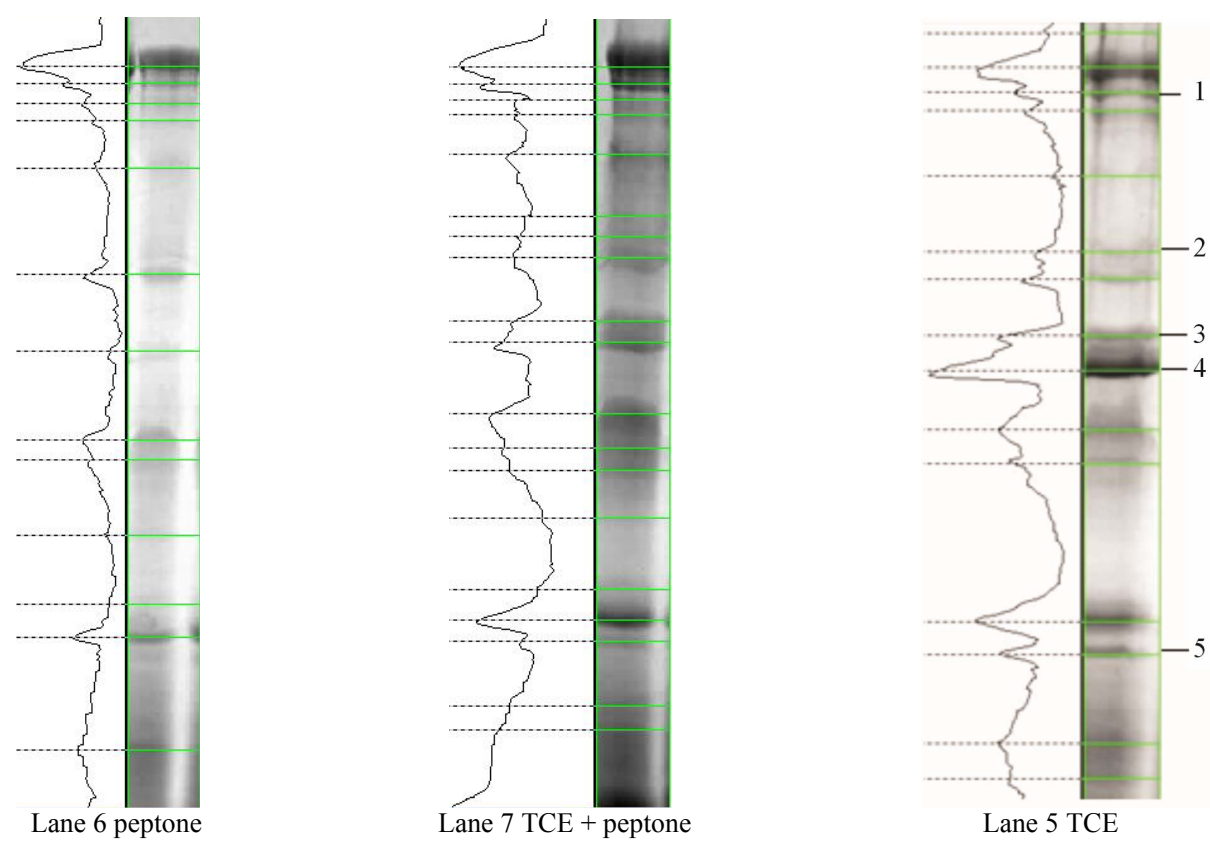

(b)

Figure 6. (a) 12\% SDS PAGE of PM102 grown in peptone, TCE + peptone and only TCE. Lanes 6 and 8 show proteins extracted from PM102 grown in 0.2\% peptone. Lanes 2, 3, 4, 7, 9 and 10 contains proteins obtained from PM102 grown in $0.2 \%$ TCE with $0.2 \%$ peptone. Lanes 5,11 and 12 contains proteins extracted from the same isolate grown in $0.2 \%$ TCE. Lane 13 contains BSA while lane 1 has molecular weight marker of medium and low range. All molecular weight markers are in kDa. (b) Densitometric analysis of the $12 \%$ gel by Quantum Capt software showing the differential expression of proteins under varying culture conditions $-0.2 \%$ peptone, $0.2 \%$ TCE with $0.2 \%$ peptone and $0.2 \%$ TCE.

paper, will provide in depth knowledge at the metabolic and genetic level.

\subsection{Protein Profile}

One of the best techniques for detecting changes in metabolism is proteomics i.e. determining the complete change in protein production in the cell when it is exposed to different culture conditions. When PM102 was exposed to TCE, peptone and TCE + peptone, 5 prominent bands were detected in presence of TCE which were absent in presence of peptone, as illustrated clearly in the densitogram. These 5 proteins may be involved in the catabolic pathway that leads to TCE degradation.

\subsection{Monitoring TCE Mineralisation by Chloride Release}

In the titration experiment, it was interestingly noted that chloride release at $\mathrm{pH} 5$ commenced after 9 hours whereas at neutral $\mathrm{pH}$, chloride was release could be detected before 3 hours. The lag period noticed at $\mathrm{pH} 5$ 
coincided with the growth pattern of PM102. The growth of PM102 at pH 5 started after 72 hrs whereas at $\mathrm{pH} 6$ and 7 started after $48 \mathrm{hrs}$. After $72 \mathrm{hrs,} \mathrm{growth} \mathrm{at} \mathrm{pH} 5$ was more than that of $\mathrm{pH} 6$ and 7. Thus, at $\mathrm{pH} 5$, there was a longer lag period which may be due to the fact that acidic $\mathrm{pH}$ poses a stress condition to the growth and survival of the isolate. Many bacteria have been known to produce exopolysaccharides in response to environmental stress like low $\mathrm{pH}$ and starvation [28,29]. PM102 produced a creamy white pellicle at $\mathrm{pH} 5$ that turned the medium yellowish. Nature of this suspension was determined to be a polysaccharide by ethanol precipitation. Presence of carbohydrate was confirmed by acid hydrolysis and Molisch test.

\subsection{Immunoblotting}

Western blot analysis carried out with rabbit antisera should have given bands in response to the $51.16 \mathrm{kDa}$ protein (TCE induced) that was injected for immunisation of the rabbit. Somehow, the rabbit antiserum was found to cross react with the $46.84 \mathrm{kDa}$ protein in addition to the $51.16 \mathrm{kDa}$ band. This $46.84 \mathrm{kDa}$ protein is common to both TCE and peptone. Thus, in Western blot with the total antisera, the nitrocellulose membrane revealed bands in lane containing proteins from TCE + peptone grown cells as well as only peptone grown cells. When the antiserum was preadsorbed with peptone grown cellular proteins, all the common antibodies were removed. The preadsorbed antiserum contained antibodies specific to the $51.16 \mathrm{kDa}$ TCE induced protein and thus did not give any signal in response to the peptone grown cellular antigen. This gives a definite proof that the PM102 isolate does actually express proteins that are specific for TCE degradation.

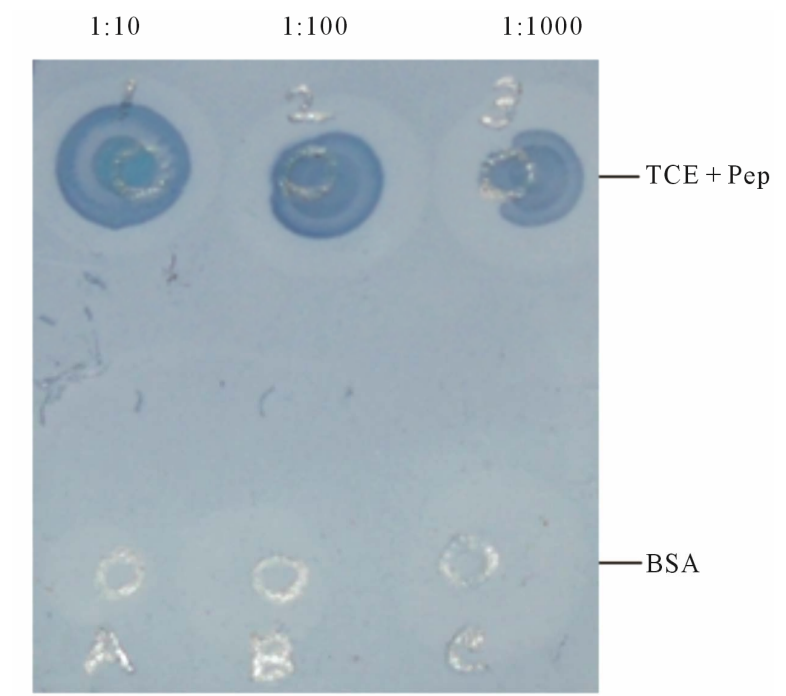

Figure 7. Dot blot assay. Spots 1, 2, 3 contained $3 \mu \mathrm{l}$ of the different dilutions of $\mathrm{Ag}$ (TCE + peptone grown proteins). Spots A, B, C had $1 \mu \mathrm{l}, 2 \mu \mathrm{l}$ and $3 \mu \mathrm{l} \mathrm{of} 1 \mathrm{mg} / \mathrm{ml}$ BSA.

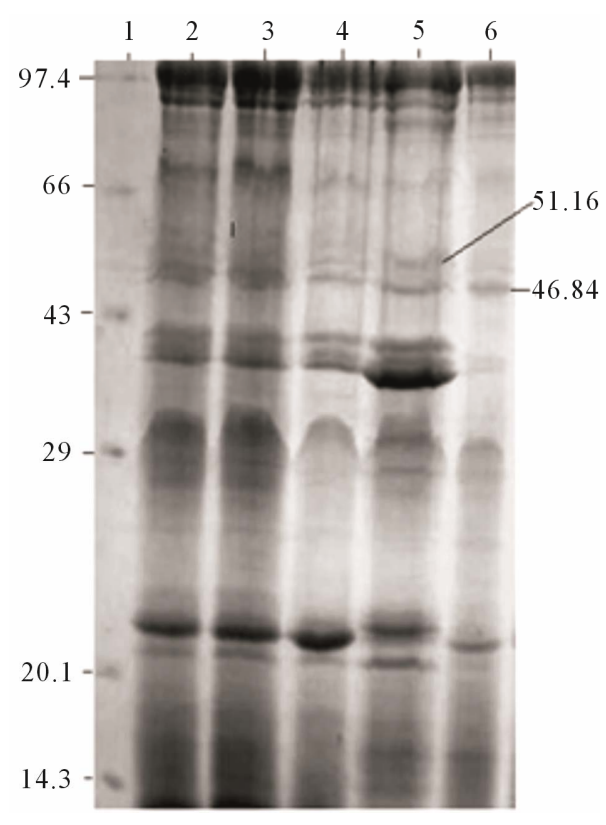

(a)

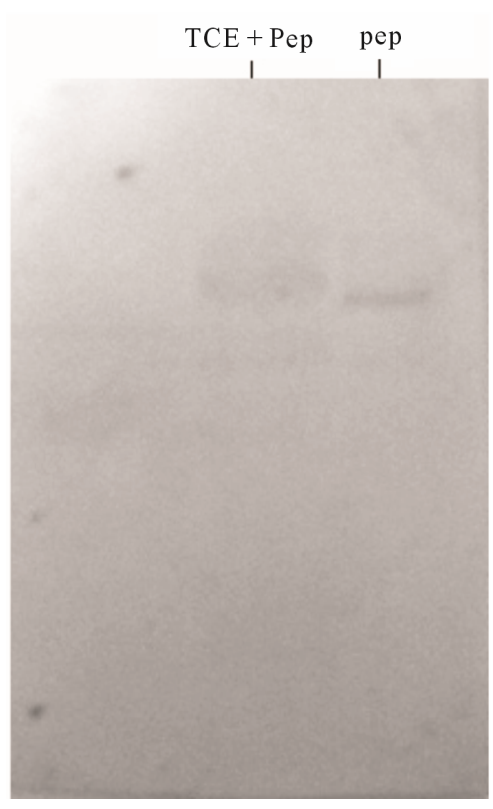

(b)

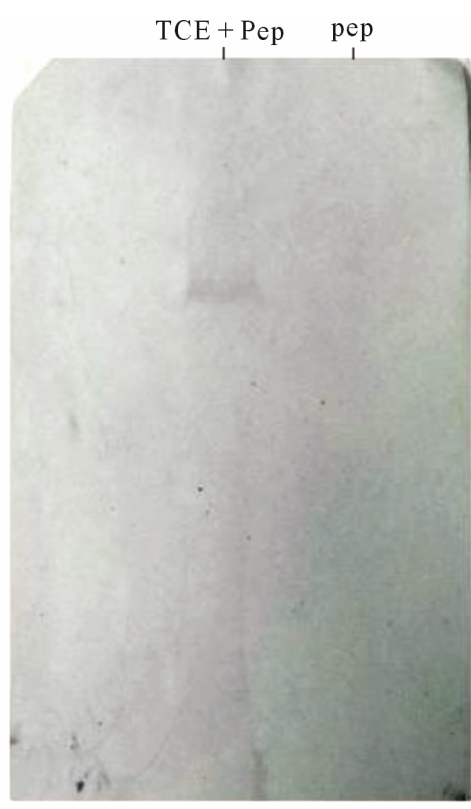

(c)

Figure 8. (a) 12\% SDS PAGE. Lane 1: Molecular weight marker, Lanes 2, 3, 4: TCE + peptone, Lane 5: TCE and Lane 6: peptone. Molecular weights of protein markers are in kDa; (b) Western blot with total antiserum. Bands seen for TCE + peptone as well as peptone grown proteins; (c) Western blot with antiserum Preadsorbed on peptone grown proteins. Band seen against TCE + peptone grown proteins. No reaction against peptone grown proteins. 


\section{Conclusions}

The isolate PM102 was capable of degrading 90\% TCE at $\mathrm{pH} 7$ after 48 hours of growth and 77\% TCE at $\mathrm{pH} 5$ after 72 hours of growth. Chloride release due to the mineralisation of TCE by PM102 was also monitored over a 30 hours time period. Through polyphasic identification strategy [30], this TCE degrader was found to be a gram negative, non lactose fermenting Xanthomonad, highly similar (99\%) to Stenotrophomonas $s p$. By studying changes in total protein expression of this isolate under different culture conditions, 5 distinguishable TCE induced bands were observed that were not present in presence of some other carbon source such as peptone. These differentially expressed proteins pinpoint towards a complex catabolic pathway involving different multicomponent enzyme systems that may be involved in TCE degradation. There is a proposed pathway of TCE degradation but the exact mechanism is still unknown [31]. Further attempts will be made to isolate the genes responsible for TCE degradation and to unravel the degradation mechanism in detail.

Thus, this novel isolate proves to be a promising bioremediation tool for eradicating a potential carcinogen like trichloroethylene from our environment.

\section{Acknowledgements}

This research work was supported by The Department of Science and Technology (DST), New Delhi, India. The authors sincerely thank DST for the grant of INSPIRE fellowship (Innovation in Science Pursuit for Inspired Research). We also acknowledge Mrigendranath Mondal endowment to our Department.

\section{REFERENCES}

[1] J. Parkhouse, "Trichloroethylene," British Journal of Anaesthesia, Vol. 37, No. 9, 1965, pp. 681-687. doi:10.1093/bja/37.9.681

[2] Fact Sheet, "Trichloroethene in Indoor and Outdoor Air," New York State Department of Health, 2005. http://www.victorny.org/Data/FileManager/PageDownloa ds/Town/Modock/TCE_Facts.pdf

[3] Chapter 5.15, "Trichloroethylene, Air Quality GuideLines," World Health Organization, 2000. http://www.euro.who.int/document/aiq/5_15trichloroethyl ene.pdf

[4] "Documentation of Threshold Limit Values and Biological Exposure Indices," 6th Edition, American Conference of Governmental Industrial Hygienists, Cincinnati, 1991.

[5] "Substances Found at Proposed and Final NPL Sites through Update Number Three," US Environmental Protection Agency, Washington DC, 1985, Document NPLU3-6-3.

[6] G. J. Hathaway, N. H. Proctor, J. P. Huges and M. L.
Fischman, "Chemical Hazards of the Workplace," 3rd Edition, Van Nostrand Reinhold, New York, 1991.

[7] R. Oldenhuis, R. L. J. M. Vink, D. B. Janssen and B. Witholt, "Degradation of Chlorinated Aliphatic Hydrocarbons by Methylosinus trichosporium OB3b Expressing Soluble Methane Monooxygenase," Applied and Environmental Microbiology, Vol. 55, No. 11, 1981, pp. 28192826.

[8] Alvarez-Cohen and P. L. McCarty, "Product Toxicity and Cometabolic Competitive Inhibition Modeling of Chloroform and Trichloroethylene Transformation by Methanotrophic Resting Cells," Applied and Environmental Microbiology, Vol. 57, No. 4, 1991, pp. 1031-1037.

[9] K. J. Malachowsky, T. J. Phelps, A. B. Teboli, D. E. Minnikin and D. C. White, "Aerobic Mineralization of Trichloroethylene, Vinyl Chloride, and Aromatic Compounds by Rhodococcus Species," Applied and Environmental Microbiology, Vol. 60, No. 2, 1994, pp. 542-548.

[10] M. J. K. Nelson, S. O. Montgomery and P. H. Pritchard, "Trichloroethylene Metabolism by Microorganisms That Degrade Aromatic Compounds," Applied and Environmental Microbiology, Vol. 54, No. 6, 1988, pp. 604-606.

[11] Y. Kamagata, T. Kanagawa, R. Kurane, H. Zhang, S. Hanada, T. Shigematsu and K. Shibuya, "Burkholderia kururiensis sp. nov., a Trichloroethylene (TCE)-Degrading Bacterium Isolated from an Aquifer Polluted with TCE," International Journal of Systematic and Evolutionary Microbiology, Vol. 50, No. 2, 2000, pp.743-749. doi:10.1099/00207713-50-2-743

[12] B. R. Folsom, P. J. Chapman and P. H. Pritchard, "Phenol and Trichloroethylene Degradation by Pseudomonas cepacia G4: Kinetics and Interactions between Substrates," Applied and Environmental Microbiology, Vol. 56, No. 5, 1990, pp. 1279-1285.

[13] L. P. Wackett and D. T. Gibson, "Degradation of Trichloroethylene by Toluene dioxygenase in Whole-Cell Studies with Pseudomonas putida Fl," Applied and Environmental Microbiology, Vol. 54, No. 7, 1988, pp. 17031708.

[14] M. S. Shields and M. J. Reagin, "Selection of a Pseudomonas cepacia Strain Constitutive for the Degradation of Trichloroethylene," Applied and Environmental Microbiology, Vol. 58, No. 12, 1992, pp. 3977-3983.

[15] M. E. Rasche, M. R. Hyman and D. J. Arp, "Factors Limiting Aliphatic Chlorocarbon Degradation by Nitrosomonas europaea: Cometabolic Inactivation of Ammonia Monooxygenase and Substrate Specificity," Applied and Environmental Microbiology, Vol. 57, No. 10, 1991, pp. 2986-2994.

[16] D. Arciero, T. Vannelli, M. Logan and A. B. Hooper, "Degradation of Trichloroethylene by the AmmoniaOxidizing Bacterium, Nitrosonionas europaea," Biochemical and Biophysical Research Communications, 1989, Vol. 159, No. 2, pp. 640-643. doi:10.1016/0006-291X(89)90042-9

[17] L. P. Wackett, G. A. Brusseau, S. R. Householder and R. S. Hanson, "Survey of Microbial Oxygenases: Trichloroethylene Degradation by Propane-Oxidizing Bacteria," 
Applied and Environmental Microbiology, Vol. 55, No. 11, 1989, pp. 2960-2964.

[18] P. Pant and S. Pant, "A Review: Advances in Microbial Remediation of Trichloroethylene (TCE)," Journal of Environmental Sciences, Vol. 22, No. 1, 2010, pp. 16-126. doi:10.1016/S1001-0742(09)60082-6

[19] K. Dey and P. Roy, "Degradation of Trichloroethylene by Bacillus sp.: Isolation Strategy, Strain Characteristics, and Cell Immobilization," Current Microbiology, Vol. 59, No. 3, 2009, pp. 256-260. doi:10.1007/s00284-009-9427-6

[20] S. Yamamura, Y. Morita, Q. Hasan, K. Yokoyama and E. Tamiya, "Keratin Degradation: A Cooperative Action of Two Enzymes from Stenotrophomonas sp.," Biochemical and Biophysical Research Communications, Vol. 294, No. 5, 2002, pp. 1138-1143. doi:10.1016/S0006-291X(02)00580-6

[21] B.-H. Zhou, R.-F. Yuan, C.-H. Shi, L.-Y. Yu, J.-N. Gu and C.-L. Zhang, "Biodegradation of Geosmin in Drinking Water by Novel Bacteria Isolated from Biologically Active Carbon," Journal of Environmental Sciences, Vol. 23, No. 5, 2011, pp. 816-823. doi:10.1016/S1001-0742(10)60458-5

[22] S. Rousseaux, A. Hartmann and G. Soulas, "Isolation and Characterization of New Gram-Negative and Gram-Positive Atrazine Degrading Bacteria from Different French Soils: Sandrine," FEMS Microbiology Ecology, Vol. 36, No. 2-3, 2001, pp. 211-222. doi:10.1111/j.1574-6941.2001.tb00842.x

[23] Z. Liu, C. Yang and C. Qiao, "Biodegradation of p-Nitrophenol and 4-Chlorophenol by Stenotrophomonas sp.," FEMS Microbiology Ecology, Vol. 277, No. 2, 2007, pp. 150-156. doi:10.1111/j.1574-6968.2007.00940.x

[24] G. Urszula, G. Izabela, W. Danuta and L. Sylwia, "Isola- tion and Characterization of a Novel Strain of Stenotrophomonas maltophilia Possessing Various Dioxygenases for Monocyclic Hydrocarbon Degradation," Brazilian Journal of Microbiology, Vol. 40, No. 2, 2009, pp. 285 291.

[25] M. W. Reij, J. Kieboom, J. A. M. De Bont and S. Hartmans, "Continuous Degradation of Trichloroethylene by Xanthobacter sp. Strain Py2 during Growth on Propene," Applied and Environmental Microbiology, Vol. 61, No. 8, 1995, pp. 2936-2942.

[26] M. S. Moss and H. J. Rylance, "The Fujiwara Reaction: Some Observation on the Mechanism," Nature, 1966, Vol. 210, pp. 945-946. doi:10.1038/210945a0

[27] T. Gregersen, "Rapid Method for Distinction of Gram Negative from Gram Positive Bacteria," Applied Microbiology and Biotechnology, Vol. 5, No. 2, 1978, pp. 123127.

[28] C. C. Ling, "Bacterial Polysaccharides: Current Innovations and Future Trends," Caister Academic Press, Norfolk, 1999.

[29] M. Dilworth, F. G. Rynne, J. M. Castelli, A. I. VivasMarfisi and A. R. Glennt, "Survival and Exopolysaccharide Production in Sinorhizobium rneliloti WSM419 Are Affected by Calcium and Low pH," Microbiology, Vol. 145, 1999, pp. 1585-1593.

[30] P. Van Damme, B. Pot, M. Gillis, P. Devos, K. Kersters and J. Swings, "Polyphasic Taxonomy, a Consensus Approach to Bacterial Systematic," Microbiological Reviews, Vol. 60, No. 2, pp. 407-438.

[31] M. Whittaker, D. Monroe, D. Junoh and S. Anderson, "TCE Degradation Pathway," 2006. http://unbbd.msi.umm.edu 